1110

日本機械学会論文集 $(\mathrm{A}$ 編 $)$

76 巻 768 号 $(2010-8)$

論文 No. 09-1104

\title{
三層三次元異材接合体角部の特異応力場に対する接着層厚さの影響* (外力が作用する場合)
}

\author{
古口日出男林, 中島正人*2
Influence of Adhesive Layer Thickness on Intensity of Stress Singularity at a Vertex in Three-Dimensional Joints with Three Layers \\ (In Case of External Loading)
}

\author{
Hideo KOGUCHI*3 and Masato NAKAJIMA
} *3 Department of Mechanical Engineering, Nagaoka University of Technology,
1603-1 Kamitomioka-machi, Nagaoka-shi, Niigata, 940-2188 Japan

\begin{abstract}
Influence of interlayer thickness on stress fields at a vertex in three-dimensional adhesive joints with three layers is evaluated using eigen analysis and boundary element method (BEM) using fundamental solutions for two-phase materials. A model for analysis is three-layered joints consisting of $\mathrm{Si}$, resin and $\mathrm{FR}-4$.5. A relationship between singular stress fields and the interlayer thickness is precisely investigated. All stress components are expressed in spherical coordinate systems in which origins are located at the vertex of each interface. Expression for stress, $\sigma_{\theta \theta}$, near the vertex on the interface is firstly derived from the result of eigen analysis. The order of singularity for $\mathrm{Si}^{-}$ resin interface is larger than that for resin-FR-4.5 interface. A coefficient of the power-law term in the stress expression for the distance from the vertex increases as resin thickness, the interlayer thickness, increases. The coefficient is demonstrated an upper limit when the resin thickness is larger than the width of the model. Value of coefficient in the power-law term of the angular function derived from BEM is a constant near that derived from eigen anlaysis for angular function on $\mathrm{Si}^{-}$ resin interface. Three-dimensional intensity of singularity at the vertex of interface in threedimensional joints is defined considering the intensities of singularity for radial direction and the angular function. Variation of the three-dimensional intensity of singularity at the vertex with the resin thickness is similar to that of the intensity of singularity for the radial direction.
\end{abstract}

Key Words: Stress Singularity, Interface, Adhesive Joint, Boundary Element Method, Reliability

\section{1. 緒}

\section{言}

著者らは、これまで三次元異材接合体の界面端部で生 じる特異応力場の特性を解明することを目指して研究 を行ってきた (1)-(7). 異材接合体の界面端部に生じる特 異応力場は，図!に示すように界面と自由表面との交線 である特異応力線の影響を受けた三次元的な応力場と なると考えられる。近年，著者らは，特異応力線の影響 を考慮して界面内の応力場の角度低存関数を定義し。こ れを利用して三次元特異応力場を表す式を提案した (5).

一方，著者らは高性能かつ小型化が進む電子デバイス の強度評価に関する研究を行っている，近年の電子デバ イスには CSP (Chip Size Package) 等の高密度パッケー

* 原稿受付 2009 年 12 月 22 日。

*I 正負, フエロ--, 長岡技術科学大学工学部 (画 940-2188 長岡 汸上䈏岡町 1603-1).

*2 長岡技術科学大学院工学研究科機械創造工学専攻.

E-mail : koguchi@mech.nagaokaut.ac.jp
ジが使用されている，CSPはICチップが封止樹脂で基 板に接着された構造をしており，年々ICチップ，封止 樹脂，基板の厚さが薄くなってきている。そこで本研究 ではCSPで用いられている材料の組み合わせに対して， 特に接着層の厚みが界面角部の特異応力場に与える影 響について明らかにする。

ところで, CSPを想定したシリコン(Si) と基板 (FR4.5)を接着剈(resin) で接着した三層接合体モデルに対

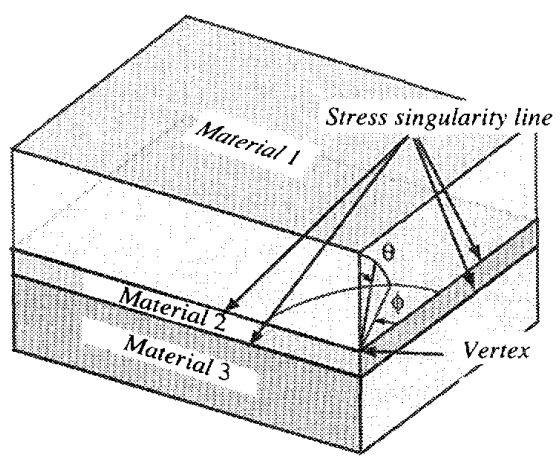

Fig. 1 Three-dimensional joint with three layers 
する熱残留応力の特異応力場については既に報告した (6). 本報ではその三層接合体の界面に垂直な方向に外力 が作用する場合の解析を行う。そして, 界面強度に最も 関係があると考えられる応力成分 $\sigma_{\theta \theta}$ の界面端近傍の特 異応力場の分布を調べ, その特異応力場の強さを求め る. 特に三層接合体の場合, 二つの界面が近づくと界面 端の特異性のオーダの異なる特異応力場が互いに干渉 することになる。これまでのところ, 界面間距離（接着 㬝厚さ）と干涉の大きさの関係はよくわかっていない. そこで, 本研究では各接合界面上における三次元的な特 異応力場の強さと接着層厚みとの関係および特異応力 場の干涉について明らかにすることを目的とする。

\section{2. 解析方法}

$2 \cdot 1$ 三次元境界要素法 三次元異材接合体内にお ける任意の点の変位は, 次の Somigliana の式より求め ることができる。

$$
u_{i}\left(p_{l}\right)=\int_{\Gamma}\left\{U_{i j}\left(p_{l}, Q\right) t_{j}(Q)-T_{i j}\left(p_{l}, Q\right) u_{j}(Q)\right\} d S(Q)
$$

ここで, $p_{i}$ は領域の内点, $Q$ は境界上のソース点, $U_{i j}$ と $T_{i j}$ は変位と作用力の基本解, $t_{j}$ と $u_{j}$ は作用力べクト ルと変位ベクトルである. 内点の応力は, 内点のひずみ を次式で求め, Hooke 則にひずみを代入することによ り求める.

$$
u_{i, k}(P)=\int_{\Gamma}\left\{U_{i j, k}(P, Q) t_{j}(Q)-T_{i j, k}(P, Q) u_{j}(Q)\right\} d S(Q)
$$

ここで, $U_{i j, k}$ と $T_{i j, k}$ は着力点 $P$ における変位と表面力の 基本解の微分である，本研究では，基本解に Rongved の三相体の解 ${ }^{\left({ }^{(}\right)}$を使用しているため, 界面における要 素分割を必要としない. そのため, 界面上の特異応力場 を厳密に求める事が可能である、また，今回の解析モデ ルは三層体なので，領域解法を用いている。

2-2 固有值解析 特異応力場を特徴付ける特異性 オーダを有限要素法の定式化に基づく固有値解析によ り求める ${ }^{(9)}$. 固有值 $p$ は応力特異性のオーダ $\lambda$ と $\lambda=1-p$ の関係がある。この固有値 $p$ は次式の固有方程式を解く ことによって得られる。

$$
\left(p^{2}[\mathbf{A}]+p[\mathbf{B}]+[\mathbf{C}]\right)\{\mathbf{u}\}=0
$$

ここで, $[\mathbf{A}],[\mathbf{B}]$, および $[\mathbf{C}]$ は弾性定数からなる行列, $\{\mathbf{u}\}$ は変位べクトルである. 後述するように $\{\mathbf{u}\}$ から固 有值 $p$ に対する固有変位さらに応力を求めることができ る.

\section{3.解析モデルおよび解析条件}

本研究の解析モデルは, 図 2 に示すような厚さ $10 \mathrm{~mm}$ の Si と FR-4.5を接着片 (resin)により接合した三層弾

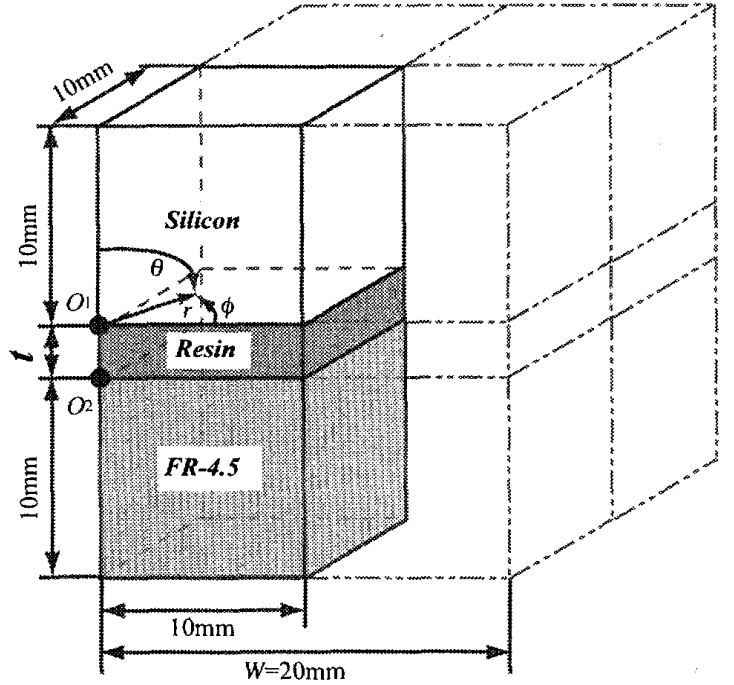

Fig.2 Model for BEM analysis

Table 1 Material properties used in analysis

\begin{tabular}{|c|c|c|}
\hline & Young's modulus & Poisson's ratio \\
\hline & $E, \mathrm{GPa}$ & $v$ \\
\hline $\mathrm{Si}$ & 166.0 & 0.26 \\
\hline Resin & 2.74 & 0.38 \\
\hline FR-4.5 & 15.34 & 0.15 \\
\hline
\end{tabular}

性体である，解析は接合体形状の対称性を考慮した 4 分 の 1 モデルで行った，解析モデルにおける接着剤の厚み $t$ は $0.002-100 \mathrm{~mm}, 14$ 種類 $(t=0.002,0.004,0.01,0.025$, $0.1,0.2,0.4,1,2,4,10,20,40,100 \mathrm{~mm})$ である. Siresin, resin-FR-4.5 の各界面角部における特異場の応力 分布を求めるため, 解析には各界面角部を原点 $\left(\mathrm{O}_{1}, \mathrm{O}_{2}\right)$ とする球座標系を用いる，解析に用いた各材料の物性 值は，表1に示す通りである．図2 の解析モデルに対 L, FR-4.5の底面の $z$ 方向変位を固定し, $\mathrm{Si}$ の上面に $P=1 \mathrm{MPa}$ の引張応力を加えて, 応力解析を行った。

\section{4. 解析結果および考察}

\section{1 固有值解析}

4-1.1 特異性オーダ 固有值解析に用いた有限要 素法モデルの要素分割図を図 3 に示す，接合体角部の応 力特異性および特異応力線上の特異性を調べるために, 要素サイズは $\theta \times \phi=9^{\circ} \times 9^{\circ}$ とした。特異応力線近傍では 後述の角度依存関数の分布を詳細に調べるため, 要素

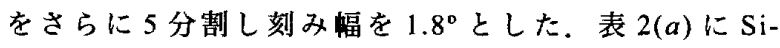
resin 接合界面の角部における特異性オーダ $\lambda_{\text {vertex }}$ と特 異線上に㧍ける特異性オーダ $\lambda_{\text {line }}$, 表 $2(b)$ にresinFR-4.5 接合界面の $\lambda_{\text {vertex }}$ と $\lambda_{\text {ine }}$ をそれぞれ示す。各接合 体において，角部と特異芯力線上で1つずつ特異性を 示すオーダが得られた。この結果より，Si-resin 界面角 部の力が resin-FR-4.5のそれよりも高い特異性を有し， さらにどちらの接合体も $\lambda_{\text {line }} よ り も \lambda_{\text {vertex }}$ の方が大きい 
Table 2 List of eigen values and order of stress singularity for vertex and line in joints

(a) $\mathrm{Si}$ - resin interface

\begin{tabular}{|c|c|c|c|c|}
\hline & \multicolumn{2}{|c|}{ Stress singularity point } & \multicolumn{2}{c|}{ Stress singularity line } \\
\hline & $p_{\text {ivrer }}$ & $\lambda_{\text {verter }}$ & $p_{\text {linc }}$ & $\lambda_{\text {line }}$ \\
\hline 1 & 1.000 & 0.000 & 1.000 & 0.000 \\
\hline 2 & 1.000 & 0.000 & 1.000 & 0.000 \\
\hline 3 & 1.000 & 0.000 & 1.000 & 0.000 \\
\hline 4 & 0.605 & 0.395 & 1.000 & 0.000 \\
\hline 5 & - & - & 1.000 & 0.000 \\
\hline 6 & - & - & 0.682 & 0.318 \\
\hline
\end{tabular}

(b) Resin - FR-4.5 interface

\begin{tabular}{|c|c|c|c|c|}
\hline & \multicolumn{2}{|c|}{ Stress singularity point } & \multicolumn{2}{c|}{ Stress singularity line } \\
\hline & $p_{\text {vercic }}$ & $\lambda_{\text {vertex }}$ & $p_{\text {line }}$ & $\lambda_{\text {line }}$ \\
\hline 1 & 1.000 & 0.000 & 1.000 & 0.000 \\
\hline 2 & 1.000 & 0.000 & 1.000 & 0.000 \\
\hline 3 & 1.000 & 0.000 & 1.000 & 0.000 \\
\hline 4 & 0.781 & 0.219 & 1.000 & 0.000 \\
\hline 5 & - & - & 1.000 & 0.000 \\
\hline 6 & - & - & 0.821 & 0.179 \\
\hline
\end{tabular}

ことがわかる。また，固有值解析の結果より対数特異性 の存在が示唆されているが, 特異応力場内の㐫力分布に 大きな影響は無いため, 以降の議論では省略し, 定数項 まで考虑することにする。したがって，接合体角部にお ける特異応力場は, 角部からの距離 $r$ に対して次式の様 に書くことができる、

$$
\sigma_{i j}(\bar{r}, \theta, \phi)=\bar{K}_{1 i j} f_{1 i j}(\theta, \phi) \bar{r}^{-\lambda_{i m m a t}}+\bar{K}_{2 i j} f_{2 i j}(\theta, \phi)
$$

ここで, $\bar{r}=r / t, \bar{K}_{k i j}$ は特異応力場の強さ， $f_{k i j}(\theta, \phi)$ は固 有值に対する応力場の角度依存関数である.

\subsection{2 固有変位ベクトルから得られた角度依存関数}

図4 に接合界面角部の点を中心とする球座標系を示 す. $r$ は原点 $\mathrm{O}$ から内点 $P$ までの距離, $r_{0}$ は球の半径を 示している。式(3)の固有方程式の定式化において, 球 内の変位場は無次元距離 $\rho=r / r_{0}$ で定義されている。表 2

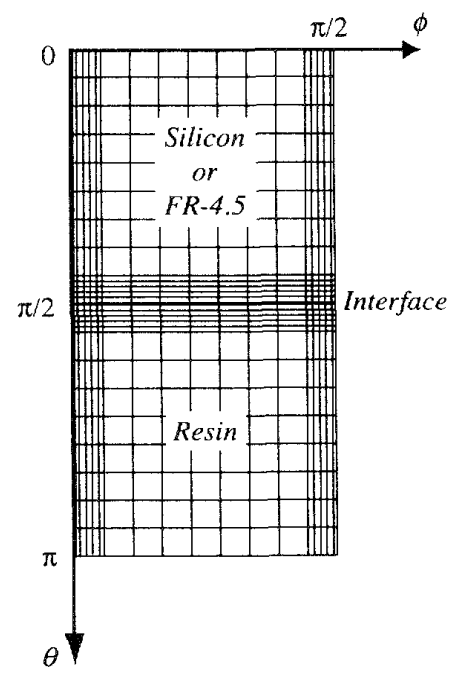

Fig. 3 A mesh on the developed $\theta \times \phi$ plane

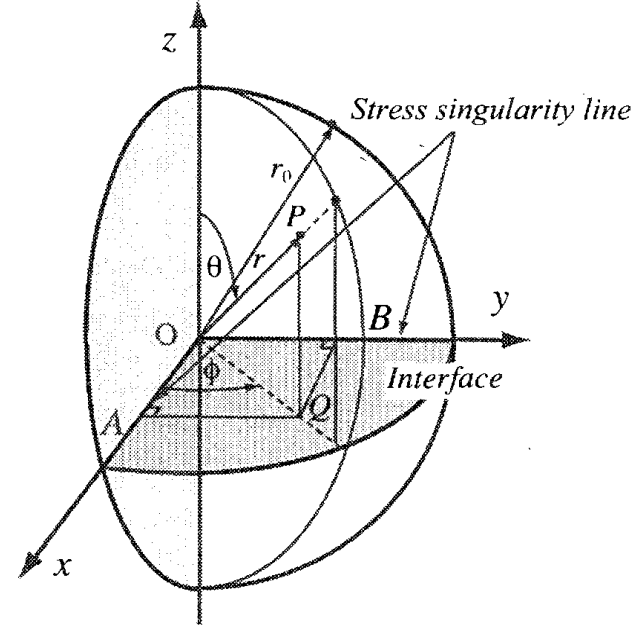

Fig.4 Spherical coordinate system with an origin at the singularity point

に示した特異性オーダに対応する式 (3) の固有べクトル $\{\mathbf{u}\}$ から, 球座標系の応力成分に対する $\rho=1$ 上の角度依 存関数を求めることができる。ここでは, 界面端部に生 じるはく離に最も関係する $\sigma_{\theta \theta}$ に対する角度依存関数の う，式 (4)の指数項 $f_{1 \theta \theta}(\theta, \phi)$ の界面上の分布について

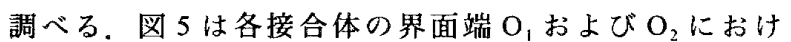
る界面上の角度依存関数 $f_{1 \theta \theta}$ をにに対して示したもので ある (図 2 参照)。ここで, $f_{1 \theta \theta}$ は界面上の角部の中心 $\phi=45^{\circ}$ における值 $f_{1 \theta \theta}\left(\theta=90^{\circ}, \phi=45^{\circ}\right)$ で正規化してある. この分布より, Si-resin 界面の分布の方が resin-FR-4.5 界面の分布より値が大きいことがわかる。これは固有値

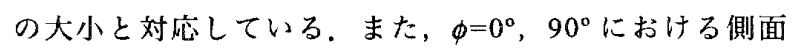
で特異性を有する分布となっている。このことから，図 4 に示す球内部の特異応力場は，接合体側面のそれぞれ

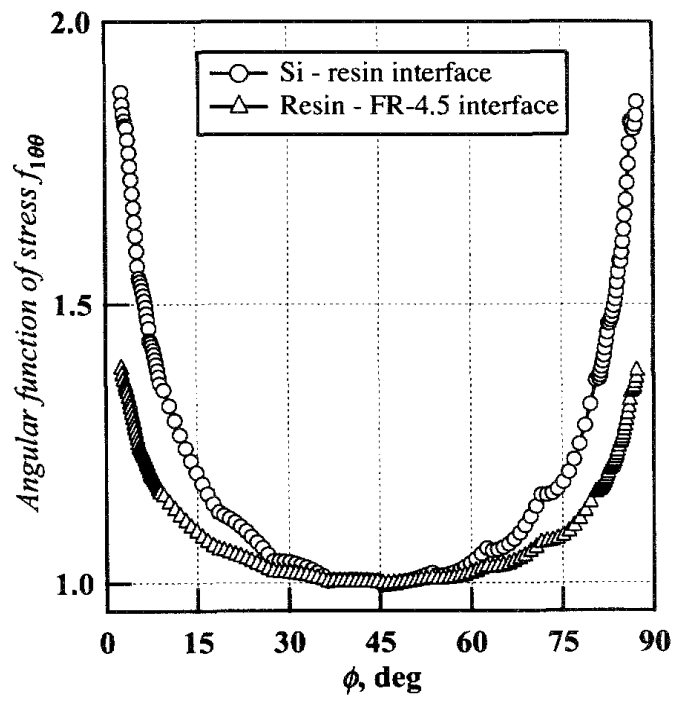

Fig. 5 Distribution of angular function, $f_{1 \theta \theta}$ : at the vertex on each interface 
Table 3 Coefficients of angular function, $L_{1 \theta \theta}^{\text {Eigen }}$ and $L_{2 \theta \theta}^{\text {Eigen }}$

\begin{tabular}{|c|c|c|}
\hline & Si - resin & resin - FR-4.5 \\
\hline$L_{1 \Leftrightarrow \theta}^{\text {Eigcn }}$ & 0.687 & 0.763 \\
\hline$L_{2 \Leftrightarrow \theta}^{\text {Eigen }}$ & -0.570 & -0.622 \\
\hline
\end{tabular}

の特異応力線からの距離に応じた影響を受けていると 推察される. 図 4 中の特異応力線 $\mathrm{OA} の$ 影響を受ける角 度依存関数を $f_{1 \theta \theta}^{\mathrm{A}}$ とすると, $f_{1 \theta \theta}^{\mathrm{A}}\left(\theta=90^{\circ}, \rho_{A}, \phi\right)=L_{1 \theta \theta}{ }^{\mathrm{A}} \rho_{A}^{-\lambda l i n e}+L_{2 \theta \theta}{ }^{\mathrm{A}}$ と書くことができる.ここで, $\rho_{A}=\rho \sin \phi$ は $A$ から $Q$ (点 $P$ の界面上への射影点）である。また，特異応力線 $\mathrm{OB}$ の影響を受ける角度依存関数 $f_{1 \theta \theta}^{\mathrm{B}}$ も同様に表すことが できる。ここでは, 簡単に特異応力場の $\phi$ 方向の角度 依存関数 $f_{1 \theta \theta}$ は，二つの特異応力線からの影響を受け， $f_{1 \theta \theta}\left(\theta=90^{\circ}, \rho_{A}, \rho_{B}, \phi\right)=L_{1 \theta \theta}{ }_{A}^{\mathrm{A}} \rho_{A}^{-\lambda l i n e}+L_{1 \theta \theta}^{\mathrm{B}} \rho_{B}^{-\lambda l i n e}+L_{2 \theta \theta}{ }^{\mathrm{A}}+L_{2 \theta \theta}^{\mathrm{B}}$ のように 書くことができるとする。なお，本解析の接合体モデル はそれぞれの側面の形状が同じなので, $L_{k \theta \theta}^{\mathrm{A}}=L_{k \theta \theta}^{\mathrm{B}}$ であり， さらに定数項はまとめると, 界面上の角部における角度 依存関数は次式のように書くことができる.

$$
f_{1 \theta \theta}\left(\theta=90^{\circ}, \rho_{A}, \rho_{B}, \phi\right)=L_{1 \theta \theta}\left(\rho_{A}^{-\lambda_{\text {tare }}}+\rho_{B}^{-\lambda_{t m r e}}\right)+L_{2 \theta \theta}
$$

図 5 の分布を式(5)で近似し，最小二乗法により係数を 求めた結果を表 3 に示す。係数を求める際には $\rho=1$ と した. 固有值解析による角度依存関数より得た結果と いうことを示すため， $L_{k \theta \theta}^{\text {Eigen }}$ とする，応力特異線の強さ として指数項の係数を考える。この結果より， $L_{1 \theta \theta}^{\text {Eigen }}$ resin-FR-4.5 接合体の力がSi-resin 接合体よりも大きい 值であることがわかる。

\section{2 境界要素法による解析結果}

4.2-1 Si-resin および resin-FR-4.5 界面端近傍にお ける応力分布 $(r$ 方向の分布) 外力に対する各接合 界面角部近傍の応力分布を, 前述の境界要素法により 求めた。各接着層厚みにおける Si-resin および resinFR-4.5 界面での $\sigma_{\theta \theta}$ の界面端からの距離 $r$ に対する分布 を図6(a),(b)に示す。図6(a)にSi-resin 界面, 図6(b) に resin-FR-4.5 界面での分布を示す。これらの結果より， $\mathrm{Si}$-resin 界面の応力の方が resin-FR-4.5 界面よりも大き いことがわかる。それぞれの界面で接着層が厚くなるに 伴い応力は大きくなる傾向がある。また，それぞれの界 面において接着層厚みが $20 \mathrm{~mm}$ 以上になると伦力が大 きくならないことがわかる。

次に，各接着層厚みにおけるSi-resinおよび resinFR-4.5 界面での $\sigma_{\theta \theta}$ の界面端からの距離 $r$ を接着層厚み tで無次元化した $r / t$ に対する分布を図7 $(a),(b)$ に示す。 横軸を無次元距離 $r / t$ とすることで, 各接着層厚みに対 する特異応力場の領域が分かり易くなる。これらの図か ら, 各接着層厚みにおいて最小值（原点に最も近い位置 での変曲点)を示す值が同じであり, Si-resin 界面では

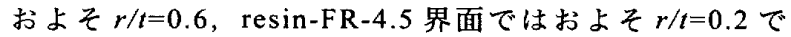

あることがわかる。このことより，特異応力場の範囲は 接着層の厚み等の接合体形状によって決まると考えら れる。

図 7 に示す応力分布は式 (4)で表されるが，実際の応 力分布は図 6 に示すものである。そこで，新たに接着層 厚み $t$ を特異応力場の強さ $\bar{K}_{1 i j}$ に含ませた式で特異応力 場の強さを評価することが必要である，したがって，以 下に示す式をここで用いる。

$$
\sigma_{\theta \theta}(r, \theta, \phi)=K_{1 \theta \theta} f_{1 \theta \theta}(\theta, \phi) r^{-\lambda_{\text {retar }}}+K_{2 \theta \theta} f_{2 \theta \theta}(\theta, \phi)
$$

ここで， $\bar{K}_{1 \theta \theta} t^{\lambda_{\text {rrm }}}$ を新たに $K_{1 \theta \theta}$ と置いている. 式 (5)お よび式 (6)の角度依存関数 $f_{1 \theta \theta}$ は $\phi=45^{\circ}$ で 1 となる様に 正規化されている．図6を式(6) を用いて最小二乗法近

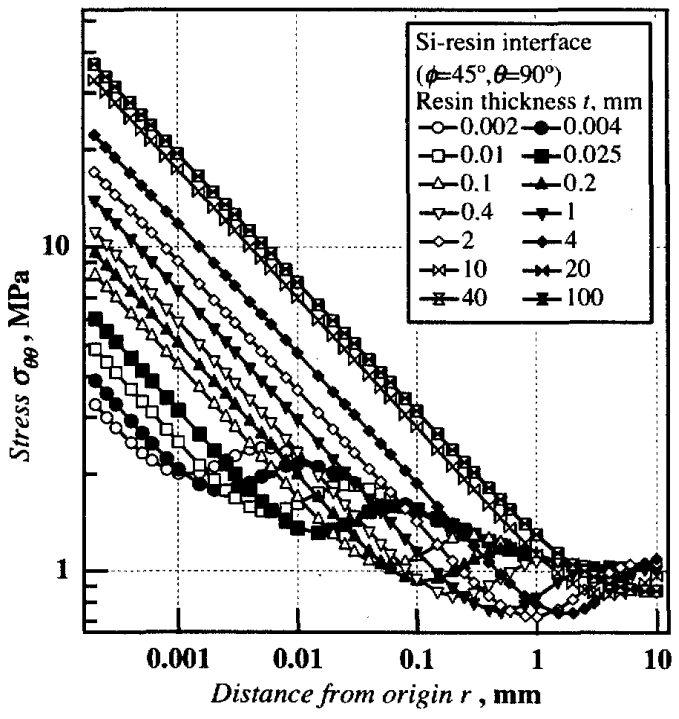

(a) $\mathrm{Si}$ - resin interface

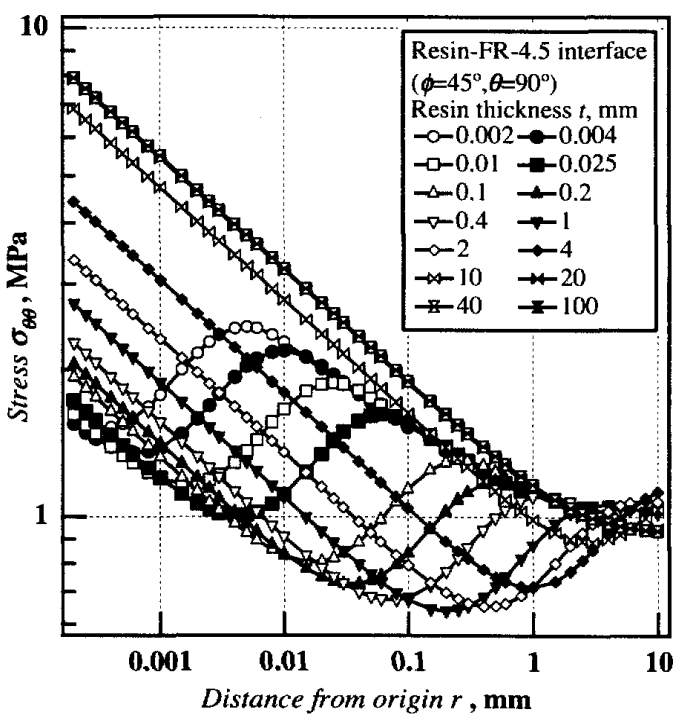

(b) Resin - FR-4.5 interface

Fig.6 Distribution of stress, $\sigma_{\theta \theta}$, against distance $r$ on each interface 
似し， $\bar{K}_{1 \theta \theta}$ を求めた。図 8 は，それぞれの界面における 特異忍力場の強さ $K_{1 \theta \theta}$ を接着層厚み $t$ に対して示したも のである。この図から，両対数グラフ上でそれぞれの界

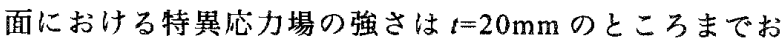
よそ $t=1 \mathrm{~mm}$ 付近で変曲点を持つ二直線形の分布で增加 していることがわかる.図6に示した応力分布と同様に， resin-FR-4.5 界面よりも Si-resin 界面の方が大きい值を 示しているが，接着層厚みが小さくなると $t=0.2 \mathrm{~mm} の$ 辺りでそれぞれの界面における分布の大小関係が逆転 し，resin-FR-4.5 界面における分布がSi-resin界面の 分布よりを大きくなる。また，それぞれの界面におい て $t=20 \mathrm{~mm}$ 以上になると上限值を示している。このこ

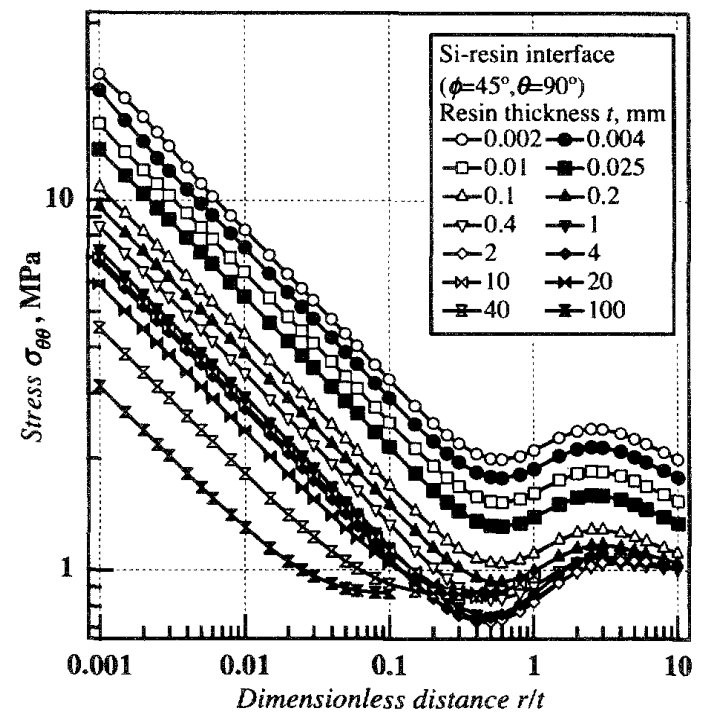

(a) $\mathrm{Si}$ - resin interface

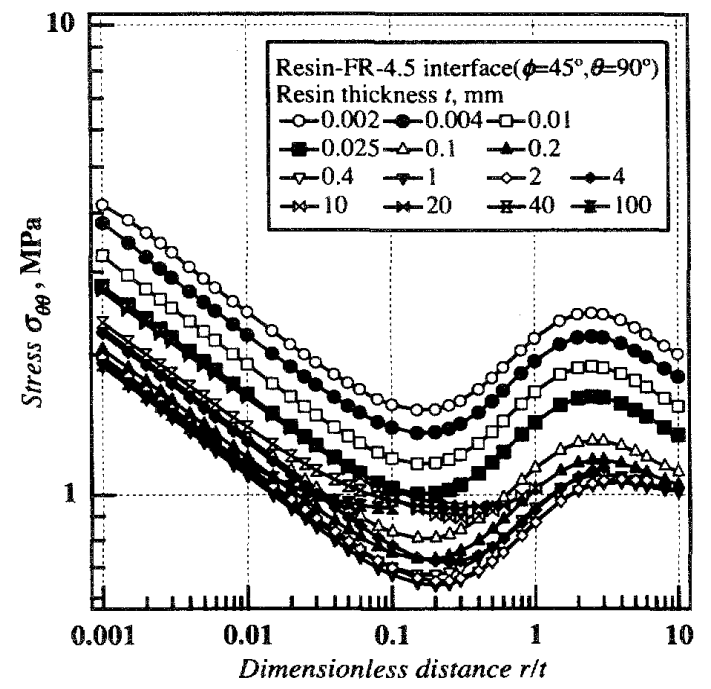

(b) Resin - FR-4.5 interface

Fig.7 Distribution of stress, $\sigma_{\theta \theta}$, against dimensionless distance $r / t$ on each interface
とから, 接着層の厚み $t$ がモデルの横幅 $(W=20 \mathrm{~mm})$ 以 上であると接着層の厚みは特異応力場に影響を及ぼさ ず，接着㬝が薄くなりそれぞれの界面が近付くと互いの 界面で生じている特異応力場同士が干涉することで特 異忍力場の強さが隇少していると考えられる，そこで, これらを示すために図 9 に示す三層二相体（以下で二 相体と呼ぶ）の解析を行い，図 2 に示す三層体の解析 結果と比較した。ここで，二相体に示す接着層厚みは， $t / 2=0.002,0.004,0.01,0.025,0.1,0.2,0.4,1,2,4,10$, $20,40,100 \mathrm{~mm}(t=0.004,0.008,0.02,0.05,0.2,0.4,0.8$, $2,4,8,20,40,80,200 \mathrm{~mm})$ としている.

二相体に扮ける特異忍力場の強さを求め, 接着曆厚み に対して三層体と比較したものを図 10 に示す。両分布 とも $t=20 \mathrm{~mm}$ 以上で注同じ上限值を示している。した がって，接着層の厚みがモデルの横幅 $(W=20 \mathrm{~mm})$ 以上 になると，接着層の厚みは特異㐫力場に影響を及ぼさな くなると言える。しかし，二相体における $K_{1 \theta \theta}$ の値も 接着層厚みが薄くなるに伴い低下している。そのため， 特異応力場の強さの低下は，接着層の厚み，つまり特異

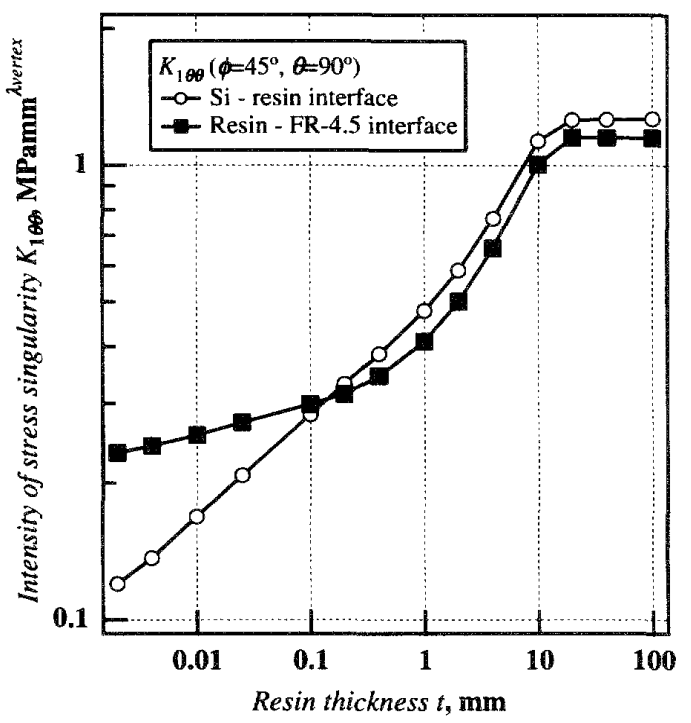

Fig.8 A relationship between $K_{1 \theta \theta}$ and $t$ of each interface

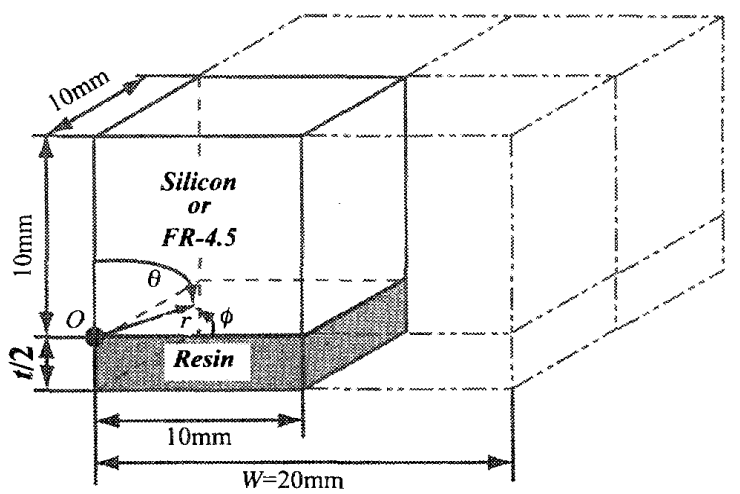

Fig.9 Three-layered two-phase model for BEM analysis 
応力場の領域が狭くなることで値が低下したものであ ると考えられる，ただし，接着層が薄くなるに伴い二相 体では両対数グラフ上で直線的に低下しているが，三層 体では $t=1 \mathrm{~mm}$ 付近で変曲点を持つ二直線形で低下して いる。この直線部分を次式で近似して傾きを調べた。

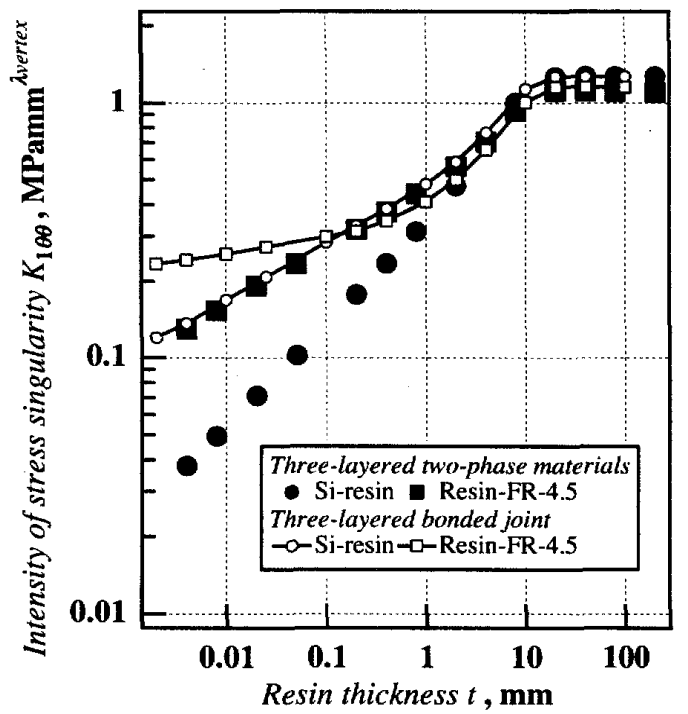

Fig. 10 A relationship between $K_{1 \theta \theta}$ which for three-layered model and for three-layered two-phase model and $t$ of each interface

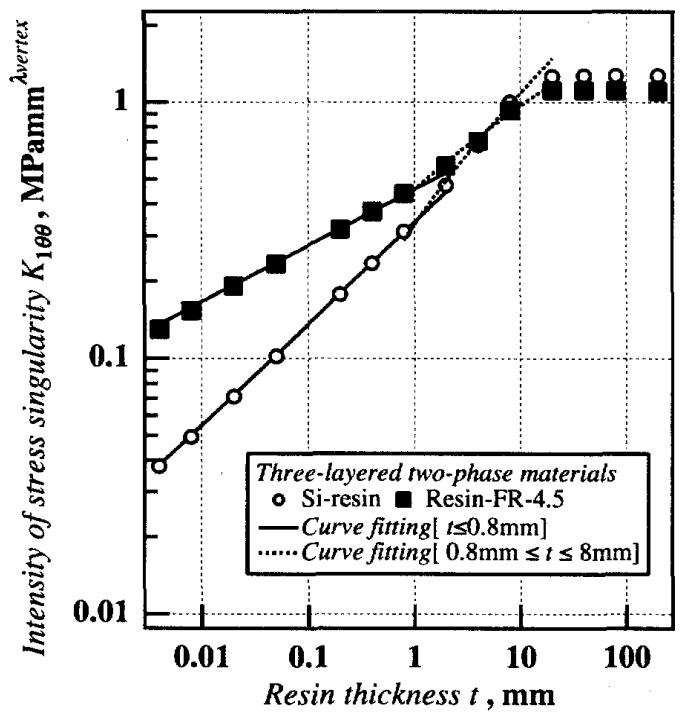

Fig.11 A relationship between $K_{1 \theta \theta}$ for two-phase model and $t$ of each joint

Table 4 Coefficients in Eq.(7)

\begin{tabular}{|c|c|c|c|c|c|}
\hline joint & range & $a$ & $b$ & $c$ & $\lambda_{\text {vertex }}$ \\
\hline \multirow{2}{*}{ Si-resin } & $\sim 0.8 \mathrm{~mm}$ & 0.33882 & 0 & 0.395 & 0.395 \\
\cline { 2 - 6 } & $0.8 \sim 8 \mathrm{~mm}$ & 0.50917 & -0.17676 & 0.395 & 0.395 \\
\hline \multirow{2}{*}{$\begin{array}{c}\text { Resin- } \\
\text { FR-4.5 }\end{array}$} & $\sim 0.8 \mathrm{~mm}$ & 0.45571 & 0 & 0.219 & 0.219 \\
\cline { 2 - 6 } & $0.8 \sim 8 \mathrm{~mm}$ & 0.78247 & -0.32757 & 0.219 & 0.219 \\
\hline
\end{tabular}

$$
K_{1 \theta \theta}=a t^{2}+b
$$

既報 (7)で示されたように二相体における三次元角部の 特異応力場の強さは接着層厚みに対する比較的簡単な関 数で表すことができた。そこで特異応力場の強さの接着 層厚みに対する関係を式 (7)で表すと, 近似の結果, 指 数 $c$ の值が表 2 で示した界面端角部における特異性の オーダ $\lambda_{\text {verrex }}$ に一致することがわかった，図 10 に示し た二相体における特異応力場の強さについて，指数 $c$ を 特異性オーダ $\lambda_{\text {verrex }}$ として式 (7)で近似した結果を実線 と破線で図 11 に示す。変曲点に近い $t=0.8 \mathrm{~mm}$ までの值 と，それ以降の $t=0.8 \sim 8 \mathrm{~mm}$ に対して得られた係数は表 4 に示す通りである。次に図 10 に示した三層体と二相 体の特異応力場の強さ $K_{1 \theta \theta}$ の比 $K_{1 \theta \theta 3 \text {-layer }} / K_{1 \theta \theta 2 \text {-phase }}$ と接着 層厚みの関係を図 12 に示す。この図は, 三層体におい て各界面端における特異性のオーダが異なる特異応力場 が近付いた時の干渉の程度を表していると考えられる。 すなわち，接着層を同じ材料で挟んだ二相体の特異応力 場の強さが, 強さの異なる特異応力場から受ける影響を 示している。この図から， $t=20 \mathrm{~mm}$ 以上ではそれぞれの 界面の干涉は生じておらず，20mm より接着層が薄くな ると干涉が生じて, Si-resin 界面では特異応力場の強さ を大きくし, resin-FR-4.5 界面では特異応力場の強さを 小さくし， $t<1 \mathrm{~mm}$ になるとそれぞれの界面において特 異応力場の強さを大きくする様な影響を及ぼしているこ とがわかる.

二相体における近似式，および三層体における干涉効 果を組み合わせることで，次式のように三層体の接着層 厚みに対する特異応力場の強さを表すことができる。

$$
K_{1 \theta \theta 3-\text { layer }}=K_{1 \theta \theta}^{\text {ratio }}\left(a t^{\lambda_{\text {nertet }}}+b\right)
$$

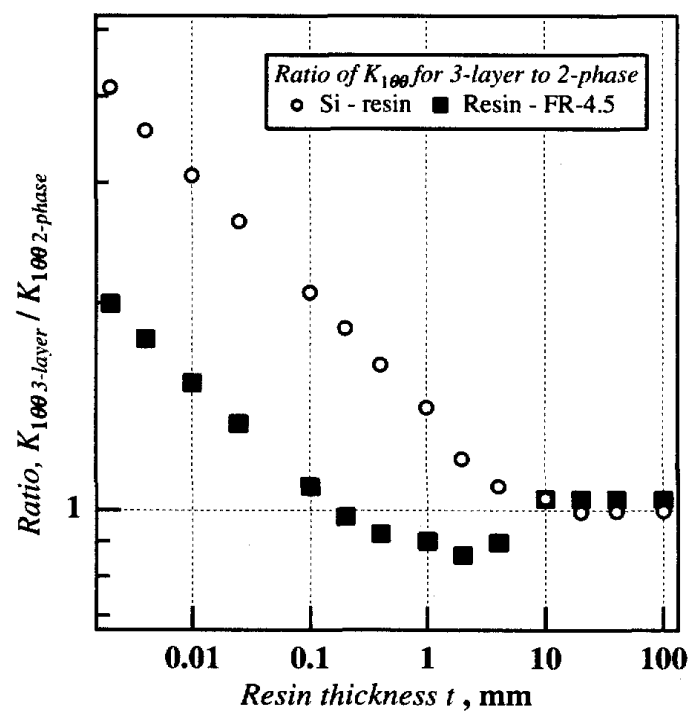

Fig.12 Ratio of $K_{1 \theta \theta}$ for three-layered model to $K_{1 \theta \theta}$ for two-phase model 
ここで, $K_{1 \theta \theta 3-\text { tayer }} / K_{1 \theta \theta 2 \text {-phase }}$ を $K_{1 \theta \theta}{ }^{\text {ratio }}$ と置いている。式 (8) を用いて, 三層体の特異応力場の強さを推定したものを 図13に示す。ここで式 (8)の係数には，接着層厚みの 範囲を $t=0.8 \mathrm{~mm}$ までと, それ以降の $t=0.8 \sim 8 \mathrm{~mm}$ とに分 けて表 4 に示す値を使用している。また $t=20 \mathrm{~mm}$ 以上 では一定值としている，接着層が厚くなると少しずれが 生じているが，三層体の特異応力場の強さは，接着層厚 みに対しておおよそ式(8)で表すことができる。

4.2.2 Si-resin およぴ resin-FR-4.5 界面端近傍にお ける応力分布（ $\phi$ 方向の分布）次に，界面上の特異 応力場における $\sigma_{\theta \theta}$ の角度 $\phi$ に対する分布を調べる。 $\phi$ に対する応力分布は，固有べクトル解析より得られた 角度依存関数 $f_{\theta \theta}$ と同じである考えられる。しかしなが

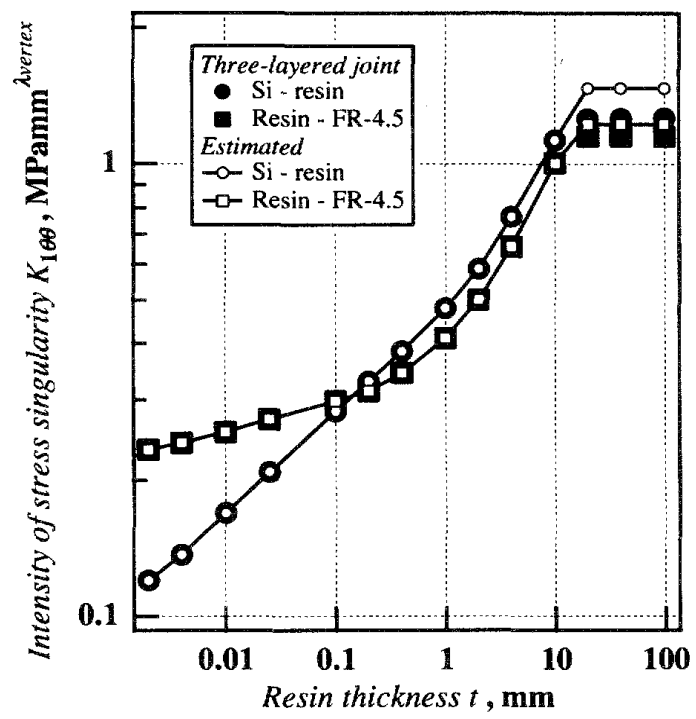

Fig. $13 K_{1 \theta \theta}$ for three-layered model estimated by Eq.(8)

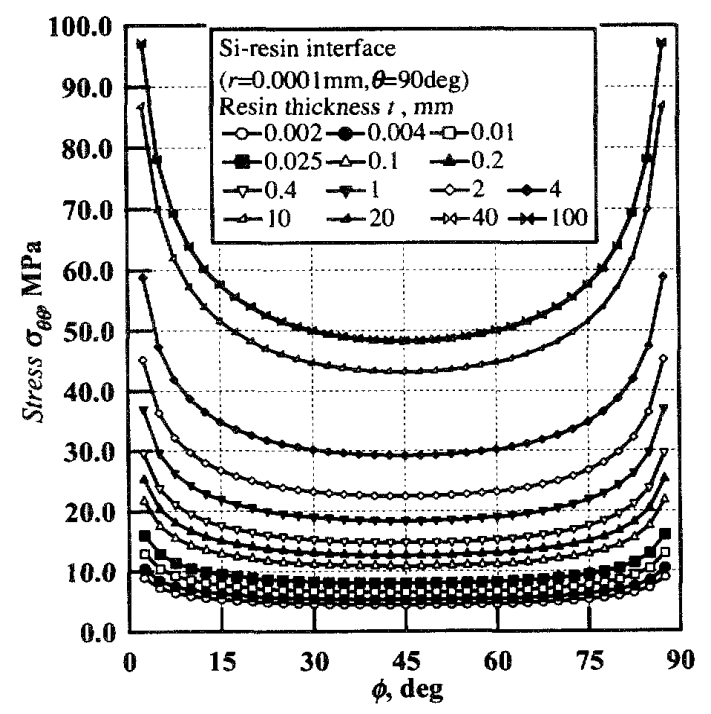

(a) $\mathrm{Si}$ - resin interface

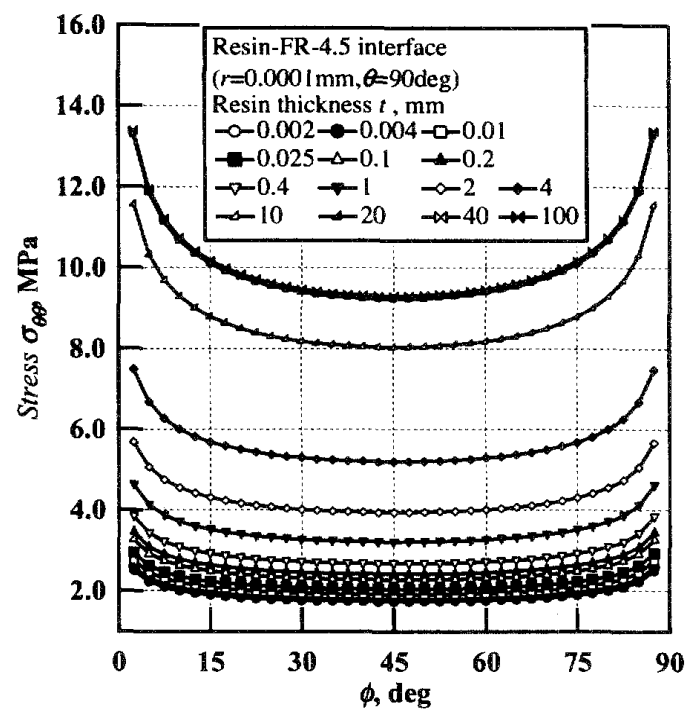

(b) Resin - FR-4.5 interface

Fig.14 Distribution of stress, $\sigma_{\theta \theta}$, against angle $\phi$ at $r=0.0001 \mathrm{~mm}$ on each interface

ら，接着層厚みの影響や，各界面間の距離が変化するこ とによる各界面での特異応力場同士の干涉，さらには 特異応力線が角部での特異応力場へ与える影響等によ り，特異応力場は複雑なものになっていると考えられ 万. 図 14(a),(b) は, 各界面上の $r=0.0001 \mathrm{~mm} の$ 位置に おける $\phi に$ 対する $\sigma_{\theta \theta}$ の分布を示している。それぞれの 界面において接着層が厚くなるに伴い応力は大きくな り， $t=20 \mathrm{~mm}$ 以上になると変わらなくなる。

この分布を $\phi=45^{\circ}$ で1 となる様に正規化し，式 (5)の 角度依存関数と同じ式を用いれば，固有べクトル解析 によって得られた角度低存関数 $f_{\theta \theta}$ と同様に特異応力線

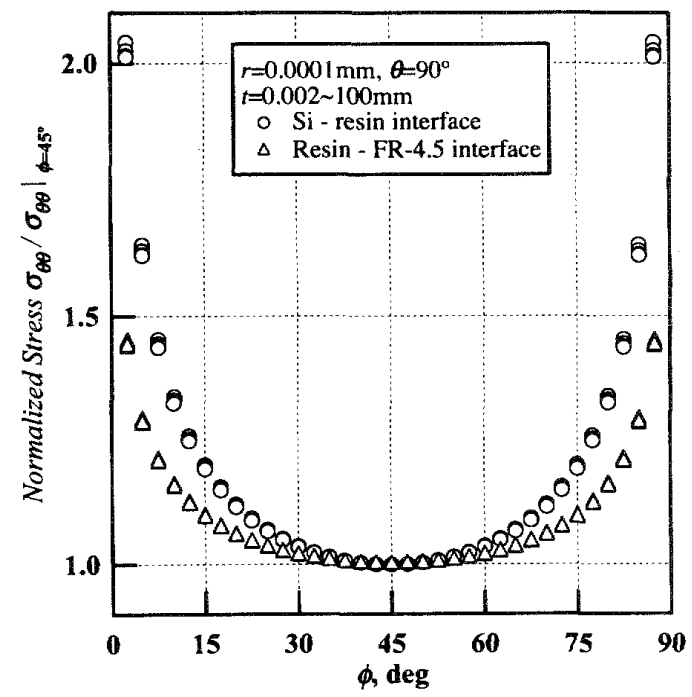

Fig. 15 Distribution of normalized stress, $\sigma_{\theta \theta}$, against angle $\phi$ at $r=0.0001 \mathrm{~mm}$ on each interface 
て係数 $L_{k \theta \theta}$ を求め, 固有べクトル解析と境界要素法によ る応力解析で得られた值の比較を行う。ただ，固有值解 析によって得られた $\phi$ に対する特異応力場の強さ $L_{1 \theta \theta}^{\text {Eigen }}$ は接着層厚み $t$ による影響を含まないため，最終的な特 異応力場の評価には次式で示すょうに境界要素法によ る結果を角度依存関数として用いることにする。

$$
g_{1 \theta \theta}\left(\theta=90^{\circ}, \rho_{A}, \rho_{B}, \phi\right)=L_{1 \theta \theta}^{\mathrm{BEM}}\left(\rho_{A}^{-\lambda_{H x}}+\rho_{B}^{-\lambda_{t m e}}\right)+L_{2 \theta \theta}^{\mathrm{BEM}} \cdots \cdots(9)
$$

ここで，固有べクトル解析による角度依存関数と区別す るため，境界要素法による $g_{1 \theta \theta}$ とした．境界要素法による $\phi$ に対する特異応力場の 強さ $L_{k \theta \theta}^{\mathrm{BEM}}$ は $L_{k \theta \theta}^{\mathrm{Eigen}}$ と違い, 界面同士の干涉効果を受け て接着層厚み $t$ によって変化する．図15に示した関係 を式(9)で近似して得られた指数項の係数 $L_{1 \theta \theta}^{\mathrm{BEM}}$ を図 16 に示す。固有値解析との比較のため， $L_{\mathrm{i} \theta \theta}^{\text {Eigen }}$ も併せて示 している.

この図から，接着層厚みに対して $L_{1 \theta \theta}^{\mathrm{BEM}}$ はほとんど 変化しないことがわかる。また，Si-resin 界面における 結果は固有值解析による同界面の結果と近いが, resinFR-4.5 界面における結果は固有值解析による同界面の 結果よりも小さい。これは, Si が FR-4.5よりも硬く変 形しにくいため, resin-FR-4.5 界面側の方が変形して応 力が低下し，固有值解析による結果より小さい值となっ たものと考えられる． $K_{1 \theta \theta}$ のように Si-resin 界面からの 干涉効果を受けて特異応力場の強さが変化しているの ではない.

4.2.3 三次元特異応力埸の強さ 界面上の特異応 力場は式 (6)で表されるが, 角度依存関数には接着層厚 みの影響を含んだ式 (9)の $g_{1 \theta \theta}$ を用いることにする。そ の結果, 特異応力場は次式のように表される.

$\sigma_{\theta \theta}(r, \theta, \phi)=K_{1 \theta \theta} g_{1 \theta \theta}(\theta, \phi) r^{-\lambda_{1 \sigma \pi t r}}+K_{2 \theta \theta} g_{2 \theta \theta}(\theta, \phi)$

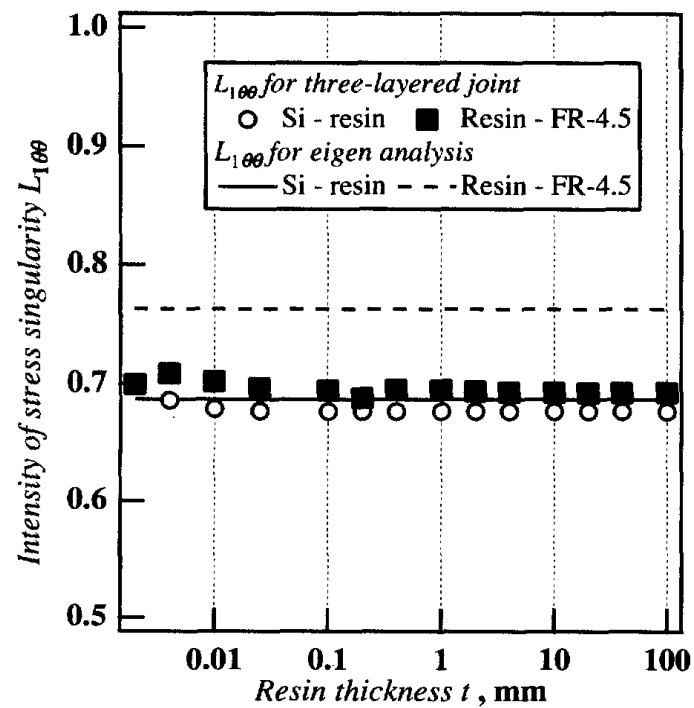

Fig. 16 A relationship between $L_{1 \theta \theta}$ and $t$ of each interface
上式に式(9)を代入し， $L_{1 \theta \theta}^{\text {BEM }}$ をくくり出せば， $r, \phi$ 方 向の特異性の強さを考慮した次式が得られる.

$$
\begin{aligned}
& \sigma_{\theta \theta}(r, \theta, \phi)=K_{1 \theta \theta} L_{1 \theta \theta}^{\mathrm{BEM}}\left(\rho_{A}^{-\lambda_{\text {text }}}+\rho_{B}^{-\lambda_{2 n t}}+\frac{L_{2 \theta \theta}^{\mathrm{BEM}}}{L_{1 \theta \theta}^{\mathrm{BEM}}}\right) r^{-\lambda_{\text {trese }}} \\
& +K_{2 \theta \theta} g_{2 \theta \theta}(\theta, \phi)
\end{aligned}
$$

ここで, 式 (11)における指数項の係数を三次元特異応 力場の強さ $K_{1 \theta \theta}^{3 \mathrm{D}}=K_{1 \theta \theta} L_{1 \theta \theta}^{\mathrm{BEM}}$ と定義する。図 17 は, 本研 究で調べた接合体のそれぞれの界面における三次元特 異応力場の強さ $K_{\mathrm{I} \theta \theta}^{3 \mathrm{D}}$ と接着層厚み $t$ との関係を示した ものである。 $L_{\mathrm{T} \theta \theta}^{\mathrm{BEM}}$ の影響によりわずかに值が変化して いるが，傾向は $K_{1 \theta \theta}$ とよく似ている. 三次元特異応力 場の強さ $K_{1 \theta \theta}^{3 \mathrm{D}}$ も $K_{1 \theta \theta}$ と同様に接着層厚み $t$ の増加に伴 い $t=1 \mathrm{~mm}$ 付近で変曲点を持つ二直線形で大きくなる。 接着層厚みがモデルの横幅以上になると接着層厚みは 三次元特異応力場に影響を及ぼさなくなる。このよう に，三次元異材接合体の角部における外力に对する特異 応力場の強さの接着層厚みに対する関係は， $\phi$ 方向に対 する特異応力場の強さの影響より，r方向に对する特異 応力場の強さが支配的となっている。

本研究では電子デバイスの CSPの信頼性を評価する ためにCSPの構成材料からなる最も簡単な積層構造の 接合体を想定し，解析を行った。実際の CSPでは基板 であるFR-4.5の上に寸法が基板とは異なる Siチップが 接着剤で接合されている。実際の CSP 寸法の接合体に 対する境界条件の違いあるいは接着郕の特性の違いに よる本研究で得られた特異応力場に関する結果への影 響は，今後の研究で明らかにしていく予定である。

\section{5. 結喜}

シリコン $(\mathrm{Si})$ ，接着郕 (resin), FR-4.5 からなる三次 元三層接合体の接着層厚みを種々に変えて, 界面端にお

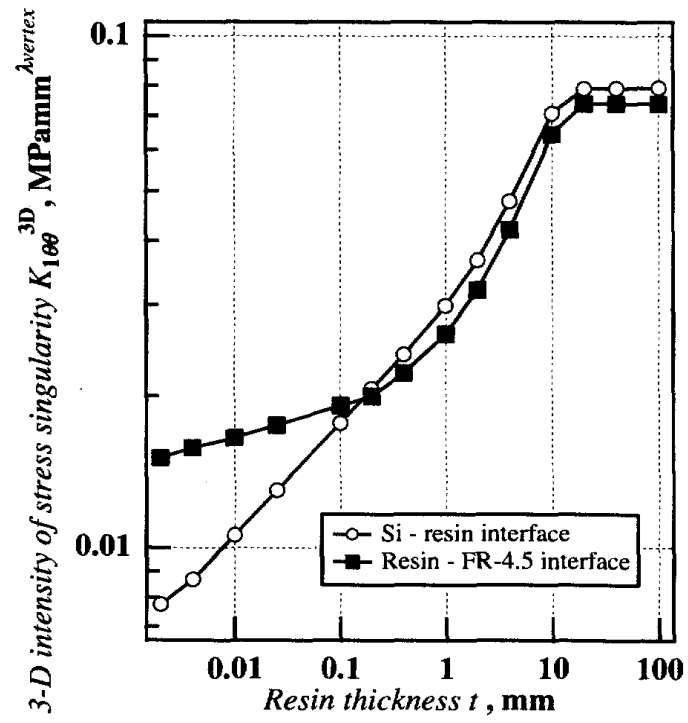

Fig. 17 A relationship between $K_{1 \theta \theta}^{3 D}$ and $t$ of each interface 
ける固有値解析および界面に垂直方向に外力が作用す る場合の応力解析を行った。そして, 界面角部で生じる 特異成力場の強さについて詳細に調べた結果, 以下のこ とがわかった。

(1)界面角部と特異応力線上における特異性オーダは, resin-FR-4.5 接合体よりもSi-resin 接合体の方が大きい，

(2) 境界要素法で得られた応力 $\sigma_{\theta \theta}$ の界面角部からの距 離に対する関係式の指数項の係数 $K_{1 \theta \theta}$ は, 接着層が厚 くなるに伴い, 雨対数グラフ上で接着層厚み 付近で変曲点を持つ二直線形で大きくなった。接着層厚 み $九$ がモデルの横幅 $20 \mathrm{~mm}$ 以上になると $K_{1 \theta \theta}$ は上限の 一定値に達した。

(3)三層体における $K_{1 \theta \theta}$ と接着層厚みの間には簡単な関 係があることを示した。

(4) 界面上の角度依存関数の角度 $\phi$ に対する分布の指数 項の係数 $L_{1 \theta \theta}^{\mathrm{BEM}}$ は, resin-FR-4.5 界面の方が大きかった。 各界面における $L_{1 \theta \theta}^{\mathrm{BEM}}$ は接着層厚みによってほとんど 変化しなかった。また, Si-resin 界面に㧍ける $L_{1 \theta \theta}^{\text {ВEM }}$ 固有值解析による $L_{1 \theta \theta}^{\text {Eigen }}$ とほとんど一致したが, resinFR-4.5 界面のそれは異なった。

(5) 三次元接合体界面角部の特異芯力場の強さ $K_{1 \theta \theta}^{3 \mathrm{D}}$ は接 着層厚さに対して, $K_{1 \theta \theta}$ と同様の傾向を示し, 厚いほど 大きくなり，モデルの横幅と同じ $t=20 \mathrm{~mm}$ 以上になる と上限の一定值に達した。

\section{文献}

(1) Koguchi, H., Fujimagari, M., Analysis for The Order of Stress Singularity, Displacement and Stress Fields at A Vertex of Three-Dimensional Joints in Electric Devices, Transactions of the Japan Society of Mechanical Engineers, Ser. A, Vol.67, No.656(2001), pp.595-602.

(2) Koguchi, H., Yamaguchi, M., Minaki, K. and Prukvilailert, M., Analysis of Stress Singularity Fields in Three-Dimensional Joints by Three-Dimensional Boundary Element Method Using Fundamental Solution for Two-Phase Transversely Isotropic Materials, Transactions of the Japan Society of Mechanical Engineers, Ser. A, Vol.69, No.679(2003), pp.585-593.

(3) Koguchi, H., Sakai, H. and Prukvilailert, M., Analysis of Stress Singularity Field in Three-Dimensional Joints Using ThreeDimensional Boundary Element Method, Transactions of the Japan Society of Mechanical Engineers, Ser. A, Vol.71, No.703(2005), pp.402-410.

(4) Monchai, P., and Koguchi, H., Boundary Element Analysis of The Stress Field at The Singularity Lines in ThreeDimensional Bonded Joints under Thermal Loading, Journal of Mechanics of Materials and Structures, Vol.2, No.1(2007), pp.149-166.

(5) Koguchi, H. and Taniguchi, T., Characteristics of Stress
Singularity Field of Residual Thermal Stresses at Vertex in Three-Dimensional Bonded Joints, Transactions of the Japan Society of Mechanical Engineers, Ser. A, Vol.74, No.742(2008), pp.864-872.

(6) Koguchi, H., and Konno, N., Intensity of Residual Thermal Stresses at the Vertex in Three-Dimensional Joints with Three Layers(Influence of Thickness of Interlayer), Transactions of the Japan Society of Mechanical Engineers, Ser. A, Vol.75, No.757(2009), pp.1148-1155.

(7) Koguchi, H., Intensity of Stress Singularity Fields at A Vertex in Three-Dimensional Bonded Joints with An Interlayer (1 st Report, In Case of A Large Difference of Young's Moduli in Interlayer and Ddherend), Transactions of the Japan Society of Mechanical Engineers, Ser. A, Vol.72, No.724(2006), pp.20582065.

(8) Rongved, 1945, Force Interior to One of Two Jointed SemiInfinite Solid, L., Proceedings Second Midwestern Conference on Solid Mechanics, pp.1-13.

(9) Pageau, S.S. and Bigger, Jr S.B., Finite Element Evaluation of Free-Edge Singular Stress Fields in Anisotropic Material, International Journal of Numerical Methods in Engineering, Vol. 38, (1995), pp.2225-2239. 